\title{
Characteristics of selected active substances used in disinfectants and their virucidal activity against ASFV
}

\author{
Małgorzata Juszkiewicz, Marek Walczak, Grzegorz Woźniakowski \\ Department of Swine Diseases, \\ National Veterinary Research Institute, 24-100 Puławy, Poland \\ malgorzata.juszkiewicz@piwet.pulawy.pl
}

Received: December 11, 2018 Accepted: February 27, 2019

\begin{abstract}
African swine fever (ASF), caused by African swine fever virus (ASFV), is currently one of the most important and serious diseases of pigs, mainly due to the enormous sanitary and socio-economic consequences. It leads to serious economic losses, not only because of the near $100 \%$ mortality rate, but also through the prohibitions of pork exports it triggers. Currently neither vaccines nor safe and effective chemotherapeutic agents are available against ASFV. The disease is controlled by culling infected pigs and maintaining high biosecurity standards, which principally relies on disinfection. Some countries have approved and/or authorised a list of biocides effective against this virus. This article is focused on the characteristics of chemical substances present in the most popular disinfectants of potential use against ASFV. Despite some of them being approved and tested, it seems necessary to perform tests directly on ASFV to ensure maximum effectiveness of the disinfectants in preventing the spread of ASF in the future.
\end{abstract}

Keywords: African swine fever, African swine fever virus, disinfection, biosecurity, virucidal effects.

\section{Introduction}

Pig production in Poland is one of the most important aspects of the country's food economy. In 2017, pork production accounted for over $35 \%$ of total meat production (Fig. 1) and was in second place after the production of poultry (over 48\%) (17). From 2009 to 2018, the population of pigs kept in Poland remained more or less stable, at around 12 million (Fig. 2). Considering the cornerstone which pork is, maintaining the appropriate number of pigs in Poland is a strategic goal of the food economy and can be served by ensuring a high level of pig welfare. Ensuring animal welfare among other measures involves maintaining animals free from infectious diseases. Some infectious diseases cause serious economic losses, not only through high mortality, but also through a negative impact on meat sales and exports.

African swine fever (ASF), caused by African swine fever virus (ASFV), is currently one of the most important and serious diseases of pigs, mainly due to its enormous sanitary and socio-economic consequences. Infection in breeding herds is slow but includes a significant percentage of animals, causing mortality of almost $100 \%$. It affects domestic pigs, wild boars, and warthogs of different age groups (26). As an example of the economic damage which ASF can inflict, in 2014 and 2015 the value of exports of pork and pork products from Poland, Lithuania, Latvia, and Estonia was reduced by US\$ 961 million by the disease, which was nearly $50 \%$ of the total export value. Uncontrolled spreading of ASF may have disastrous consequences if it appears in China, taking into account that China contains more than half of the world's pig population (35). Therefore, it is listed as a notifiable disease by the World Organisation for Animal Health (OIE).

ASFV was introduced into Europe in the second half of the $20^{\text {th }}$ century and emerged there for a second time in 2007 (8), when the virus reached Georgia. Then, ASFV spread to Armenia, Azerbaijan, the Russian Federation, Ukraine, Belarus, and the Baltic 
States (i.e. Lithuania, Latvia, and Estonia). The first case of ASF in Poland was recorded in 2014 (11).

ASFV is a large, enveloped DNA virus, with a capsid consisting of several concentric lipid and protein layers below the external lipid membrane and a double-stranded (ds) DNA genome of approximately 190 kilobase pairs $(15,28,44)$. It belongs to the Asfivirus genus of the Asfarviridae family. Infection is characterised by a progressive decrease in cellular protein synthesis with a concomitant increase in viral protein synthesis, due to an active mRNA degradation process. ASFV spreads directly through contact with infected pigs (aerosol), by bites of soft ticks of the Ornithodoros genus and by contact with materials or objects contaminated by virus-containing matter, such as blood, faeces, urine, or saliva. Wild boars may also spread the virus via direct contact or consumption of infected prey or carrion, therefore ASFV may be easily transferred to pig farms by humans $(11,35)$. New developments in the field of molecular research have provided hope that a useable vaccine may be possible, but no efforts to produce a vaccine against ASF have been successful so far $(7,9,20,31)$. Despite the roles of some structural virus proteins in viral infection having been recognised, the mechanisms of the immune response to ASFV remain unclear, and currently there are no effective disease control strategies against ASF $(14,32,35)$. ASFV is controlled by culling infected pigs and maintaining high biosecurity standards, and presently this seems to be the only way to stop the spread of ASF.

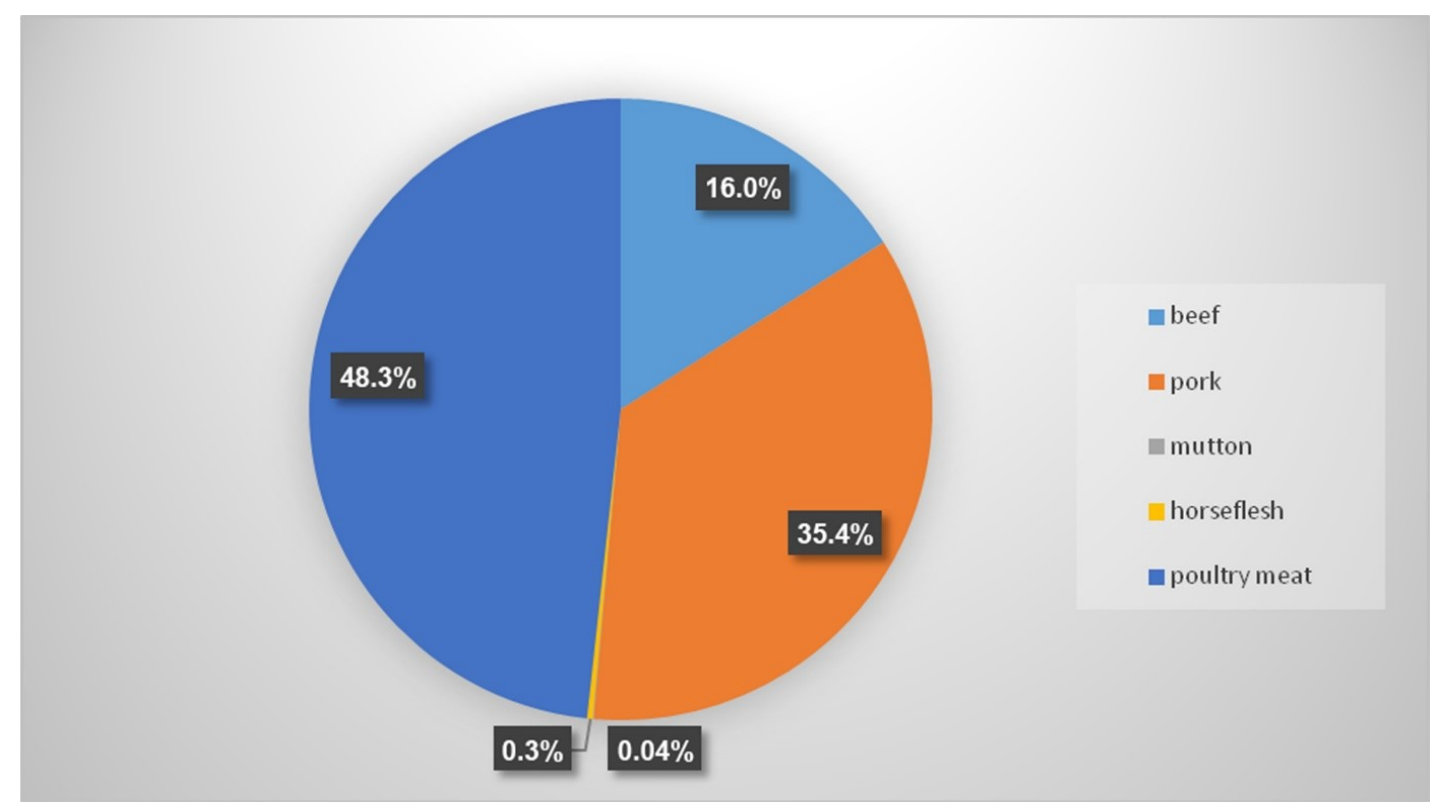

Fig. 1. Meat production in Poland in 2017

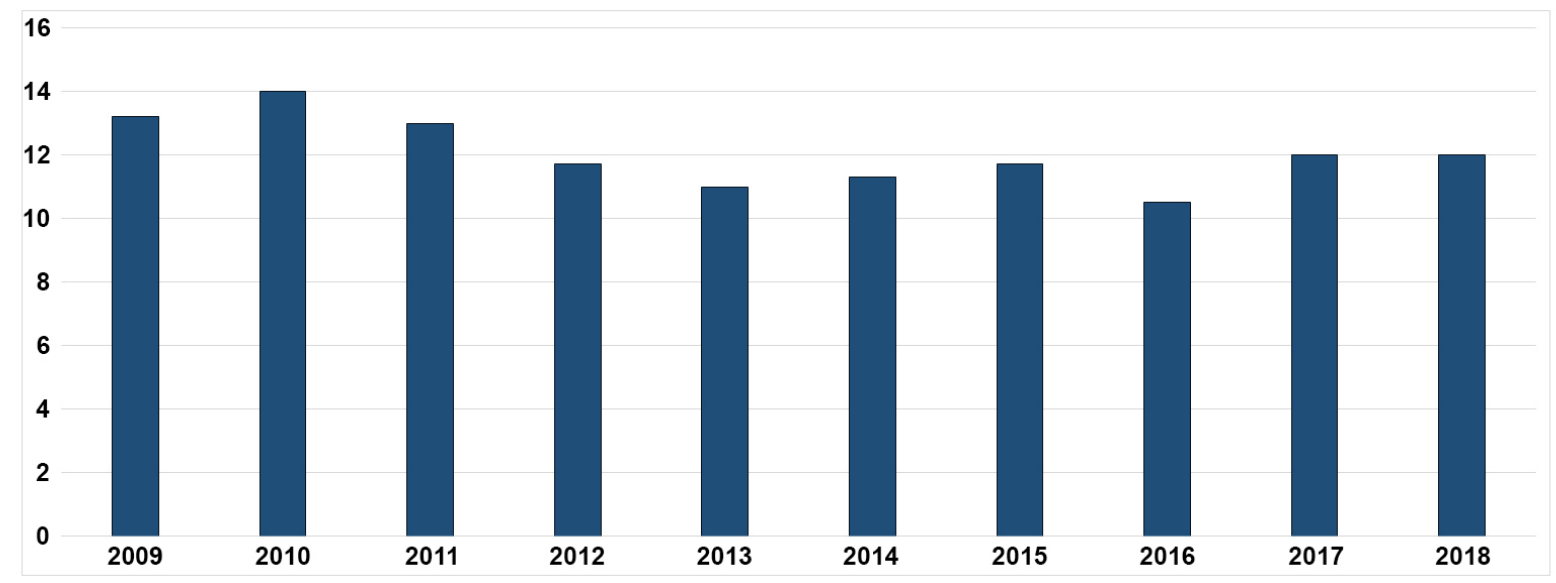

Fig. 2. Population of pigs (in millions) in Poland, 2009-2018 (18) 


\section{Biosecurity}

Biosecurity is described as prevention or minimalisation of the transmission of naturally occurring infectious diseases, pests in crops and livestock, and threats posed to the economy and environment by invasive alien organisms. Primarily, it is concerned with threats to animal and plant health and to biodiversity, which might have an indirect impact on human health (16).

Disease control is one of the most challenging fields for pork producers. Pig farm security can be defined as the planning and realisation of a programme to minimise various types of risk that can have detrimental effects on the farmstead and pigs. Many factors are involved in the development and maintenance of a cost-effective biosecurity programme. These factors can be thought of as links in a chain; a biosecurity programme is only as strong as its weakest link (19).
An important link in biosecurity is disinfection, which reduces the percentage of pathogenic microorganisms, in this case viruses, to such a degree that the disinfected object or surface is no longer a source of infection. Disinfection is vital to reduce the risk of contaminating the environment with ASFV or other pathogens. It usually occurs in two steps: a thorough mechanical cleaning followed by application of disinfectant. Potentially contaminated materials, such as manure, bedding, straw, and feedstuffs, should be removed and disposed of, and then the surface should be thoroughly washed using detergents (Fig 3.). Spraying or soaking contaminated materials rich in protein with disinfectant is ineffective because ASFV can withstand fairly extensive $\mathrm{pH}$ changes (27).

Microorganism sensitivity to chemical disinfectant action varies from the most resistant and therefore least sensitive, prions, to the least resistant and therefore most sensitive, enveloped viruses (including ASFV) (Fig. 4).

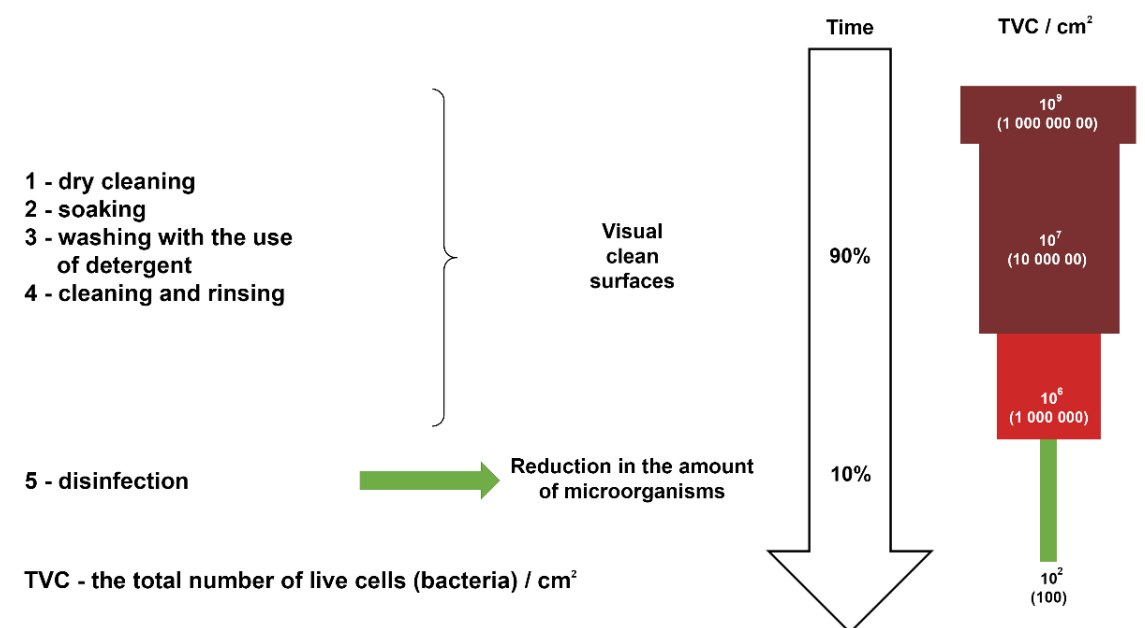

Fig. 3. Contribution of cleaning to the effectiveness of disinfection (29)

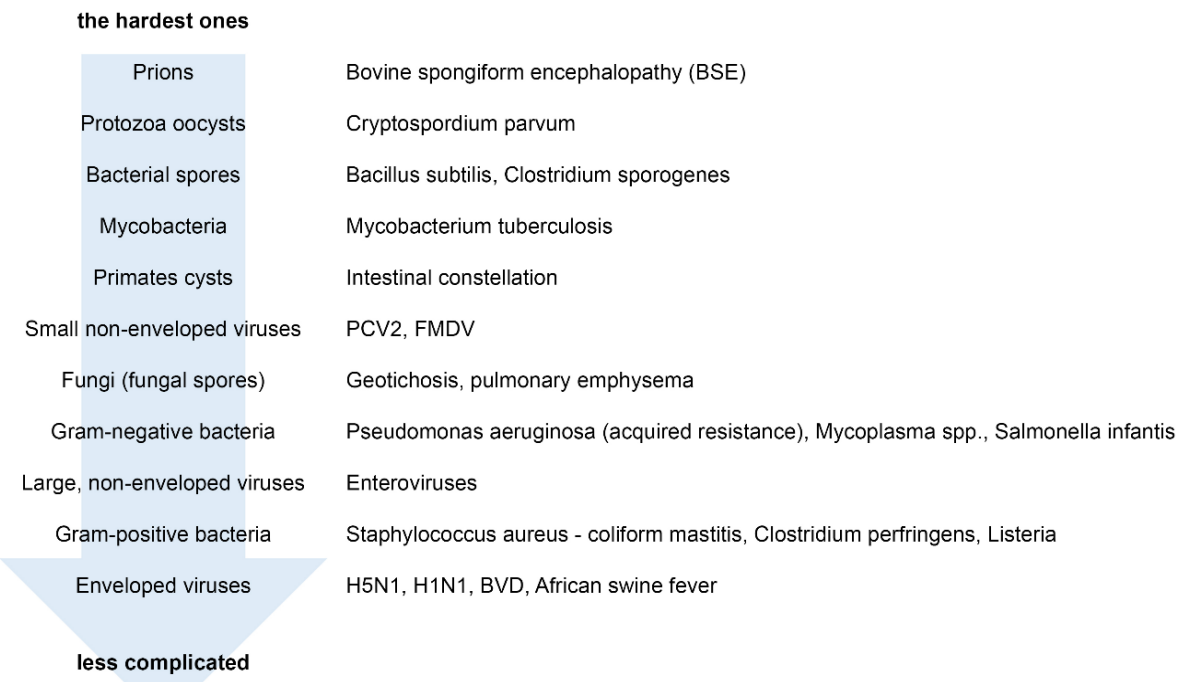

Fig. 4. Microorganisms in descending order of difficulty for disinfection $(29,34,36)$ 
Table 1. Resistance of ASFV to physical and chemical action (46)

\begin{tabular}{|c|c|}
\hline Action & Resistance \\
\hline Temperature & Highly resistant to low temperatures. Heat inactivated by $56^{\circ} \mathrm{C} / 70 \mathrm{~min} ; 60^{\circ} \mathrm{C} / 20 \mathrm{~min}$. \\
\hline $\mathrm{pH}$ & $\begin{array}{l}\text { Inactivated by } \mathrm{pH}<3.9 \text { or }>11.5 \text { in serum-free medium. Serum increases the resistance of } \\
\text { the virus, e.g., at } \mathrm{pH} 13.4 \text { resistance lasts up to } 21 \mathrm{~h} \text { without serum, and } 7 \text { days with serum. }\end{array}$ \\
\hline Chemicals/disinfectants & $\begin{array}{l}\text { Susceptible to ether and chloroform. Inactivated by } 8 / 1,000 \text { sodium hydroxide ( } 30 \mathrm{~min}) \text {, } \\
\text { hypochlorites as } 2.3 \% \text { chlorine ( } 3 \mathrm{~min}), 3 / 1,000 \text { formalin }(30 \mathrm{~min}), 3 \% \text { orthophenylphenol } \\
(30 \mathrm{~min}) \text { and iodine compounds. }\end{array}$ \\
\hline Survival & $\begin{array}{l}\text { Remains viable for long periods in blood, faeces, and tissues, especially infected uncooked } \\
\text { or undercooked pork products. Can multiply in vectors (Ornithodoros sp.). }\end{array}$ \\
\hline
\end{tabular}

Viral susceptibility to disinfectants depends on several factors, including virus type (enveloped or nonenveloped), size, morphology, and nucleic acid (singleor double-stranded) $(22,36,39)$. Non-enveloped viruses such as enteroviruses are more resistant than enveloped viruses to the action of commonly used disinfectants such as $70 \%$ alcohol and $1 \%$ quaternary ammonium compounds (6). In addition, enveloped viruses are less stable outside their hosts $(4,39)$.

Traits of the perfect disinfectant should be fast action, durability, non-toxicity, and imperviousness to environmental factors, and it should have the widest possible spectrum of biocidal activity, including against bacteria, viruses, and fungi. Precise determination of the scope of disinfectant action facilitates correct disinfection method application, and incorrect determination of activity parameters (concentration, contact time, range) may lead to improper use of disinfectant products (40) (Table 1).

Disinfection mats are the best example that the application of the above criteria ensures the effectiveness of the disinfectant. External disinfection mats are exposed to environmental influence. Wind, sunshine, and high temperature accelerate the drying, heavy rain leads to dilution of the disinfectant solution, and low winter temperatures may freeze it. It is important to check the labels and read the leaflets of disinfectants before use. There is a preferred temperature range, sensitivity to environmental conditions, use the agent is intended for, and recommended dilution guaranteeing the right $\mathrm{pH}$. The activity of most disinfectants is determined by the $\mathrm{pH}$ of the solution, which can be measured in different ways (e.g. with litmus paper). In the case of external disinfection mats soaked in acidic disinfectants, the best indicator may be the colour index of the solution, which discolours from pink (active solution) to colourless (much diminished activity) commensurately with decreasing solution activity. Another important issue is the effectiveness of disinfectants at low temperatures. Most of them used at temperatures below $-5^{\circ} \mathrm{C}$ are ineffective, especially those of an older generation. To maintain the effectiveness of disinfectants at a temperature of 0 to $-5^{\circ} \mathrm{C}$, it is necessary to add to them the appropriate amount of sodium chloride or glycol. What should always be remembered using disinfectants is to refill external disinfectant mats in winter (30).

It is hard to find the perfect disinfectant against ASFV because there is no global collation effort to gather explicitly described detailed data regarding disinfectants. However, each country has approved and/or authorised a list of biocides effective against ASFV, and thus only authorised biocides should be used and only applied according to the producer's instructions. Amassed general knowledge of and experience in the use of disinfectants against enveloped viruses, e.g. ORF virus (OV), equine viral arteritis virus (EVAV), pseudorabies virus (PRV), porcine reproductive and respiratory syndrome virus (PRRSV), and classical swine fever (CSF), have shown that the chemical compounds effective in inactivation of ASFV are as follows $(12,37)$ :

- $1 \%$ formaldehyde,

- Sodium hypochlorite $(0.03 \%$ to $0.0075 \%)$,

- $2 \%$ caustic soda solution (the strongest virucidal agent),

- Glutaraldehyde, formic,

- $1 \%$ sodium or calcium hydroxide (effective at virus inactivation in slurry at $4^{\circ} \mathrm{C}$ ),

- Phenols - lysol, lysephoform, and creolin,

- Chemical compounds based on lipid solvents,

- Multi-constituent compounds - Virkon (1:100), Lysoformin, Desoform, Octyldodeceth-20 (OD20) surfactants, active substances, organic acids, glycosal, etc.

\section{Characteristics and mechanisms of action of disinfectants}

Formaldehyde (methanal, $\mathrm{CH}_{2} \mathrm{O}$ ) is a monoaldehyde that exists as a freely water-soluble gas. It is used as a disinfectant and sterilant in liquid and gaseous states and used principally as a water-based solution called formalin, which is $37 \%$ formaldehyde $(\mathrm{w} / \mathrm{v})$. Formaldehyde is an extremely reactive chemical that interacts with protein, DNA, and RNA. The interaction is based on alkylating the amino and sulphhydryl groups of proteins and ring nitrogen atoms of purine bases. Formaldehyde is bactericidal, sporicidal, and virucidal, but it works more slowly than glutaraldehyde 
(23). Although formaldehyde is a high-level disinfectant, the uses of it are limited by its irritating fumes and pungent odour, even at very low levels ( $<1 \mathrm{ppm}$ ) (3). According to the Occupational Safety and Health Administration of the USA, it should be handled as a potential carcinogen. Formaldehyde can cause asthma-like respiratory problems and skin irritation such as dermatitis and itching, or after ingestion even death (24). This substantially limits the scope of its use as a disinfectant against ASFV. Formaldehyde is most often used against ASFV as a vapour for disinfecting electrical devices (34).

Hypochlorites are the most commonly used chlorine disinfectants and are available as liquids (e.g. sodium hypochlorite) or solids (e.g. calcium hypochlorite). Chlorine compounds are good disinfectants on clean surfaces but are quickly inactivated by organic matter and thus can significantly lose biocidal activity. Sodium hypochlorite is a hypochlorous sodium salt with the chemical formula $\mathrm{NaOCl}$ and belongs to the group of chlorine-releasing agents (CRAs). Aqueous solutions of sodium hypochlorite $(5.25 \%-6.15 \%)$ called household bleach are the most popular chlorine products used in homes. They are widely used for hard-surface disinfection, but also in the food and dairy industries and for the terminal treatment of potable water $(23,34,38)$. In water, sodium hypochlorite ionises to produce $\mathrm{Na}^{+}$and the hypochlorite ion $(\mathrm{OCl})^{-}$, which creates an equilibrium with hypochlorous acid ( $\mathrm{HOCl})(2)$. The equilibrium between hypochlorous acid and the hypochlorite ion is clearly affected by $\mathrm{pH}$. At alkaline $\mathrm{pH}$, the hypochlorite ion is favoured; the solution is relatively more stable but less effective as a disinfectant. At more acidic $\mathrm{pH}$ values, the formation of the hypochlorous acid is favoured. Although this compound is much less stable than the hypochlorite ion, it is a highly effective oxidising agent and potent antimicrobial (38). Sodium hypochlorite has a broad spectrum of antimicrobial activity. It is effective against bacteria, viruses, fungi, and spores, has a relatively low residual toxicity, and can be manufactured in large quantities at low costs, but is quickly inactivated by organic matter $(10,34)$. Although the precise mechanism of action of chlorine is not well understood, it is generally considered that the lethal effect of chlorine on microorganisms results from the oxidation (or chlorination) of cell proteins by unionised hypochlorous acid, with reactivity against a diversity of functional groups. Almost every virus tested has proved to be sensitive to some level of chlorine, and sodium hypochlorite is often recommended as a standard disinfectant for viral pathogens. It was reported that 25 different viruses were inactivated in $10 \mathrm{~min}$ with $200 \mathrm{ppm}$ available chlorine (34). Sodium hypochlorite is one of the chemical compounds recommended to inactivate ASFV because low concentrations of it are effective for disinfection. Also, research on the parapox virus using sodium hypochlorite as a disinfectant has confirmed its effectiveness in the inactivation of enveloped viruses (12). Hypochlorite is one of the disinfectants recommended for poxviruses by the OIE collaborating centre and the Institute for International Cooperation in Animal Biologics in the USA (34). Hypochlorite may be regarded as a universal disinfectant, however, its effectiveness is diminished by extended storage, and it is therefore necessary to check its activity before use. A concentration of $0.5 \%$ active chlorine appears necessary for satisfactory disinfection (47).

Sodium hydroxide (caustic soda) along with calcium hydroxide (lime) and sodium carbonate (washing soda) are members of the group of alkali chemicals. Caustic soda is a strong base. Its disinfecting action is based on the formation of free hydroxide ions, which cause protein denaturation, saponification of fats, and the distribution of carbohydrates. It has the added benefit of being effective in the presence of organic material. Sodium hydroxide has been shown to be effective at inactivating lipid-enveloped viruses such as the human immunodeficiency virus and the pseudorabies virus (15).

Table 2. The mechanisms of action of disinfectants (29)

$\begin{array}{ll}\text { Aldehydes } & \begin{array}{l}\text { Mutually bind to proteins, inhibit transport mechanisms } \\ \left.\text { Halogens (hypochlorite, iodophors, } \mathrm{ClO}_{2}\right)\end{array} \\ \begin{array}{l}\text { Penetrate the membrane and oxidise proteins, interrupt the cell's } \\ \text { oxidative phosphorylation }\end{array} \\ \text { Peroxides } & \begin{array}{l}\text { Penetrate the membrane and oxidise lipids, proteins, and DNA } \\ \text { Poison the protoplasm and damage the cellular membrane }\end{array} \\ \text { Quaternary ammonium compounds (QUATs) } & \begin{array}{l}\text { Damage the cellular membrane and disrupt the membrane, } \\ \text { cytoplasmic potential and pH gradient }\end{array} \\ \text { Biguanides } & \begin{array}{l}\text { Damage the cellular membrane and coagulate intracellular } \\ \text { constituents }\end{array}\end{array}$


Calcium hydroxide (lime) is commonly used to modify soil $\mathrm{pH}$, stabilise animal wastes, and minimise odour, and is readily available in agricultural regions. As a disinfectant, calcium hydroxide has been shown to reduce pathogen levels, particularly viruses, in slurries and waste water treatment processes. There are already two techniques exploiting its effectiveness, which have been identified as being potentially suitable for the inactivation of ASFV in pig slurry: one is heat treatment, and the other is dosing with an alkaline chemical, particularly sodium hydroxide or calcium hydroxide (42). These methods are relatively easy, generally inexpensive, and the treated slurry (especially after heat treatment) can be disposed of in the usual way. It was found that ASFV was inactivated by $\mathrm{Ca}(\mathrm{OH})_{2}$ within $30 \mathrm{~min}$ at $1 \%$ and $0.5 \%(\mathrm{w} / \mathrm{v})$ at $4^{\circ} \mathrm{C}$ and $22^{\circ} \mathrm{C} ; \mathrm{NaOH}$ was effective at $1 \%, 0.5 \%$, and $0.2 \%$ $(\mathrm{w} / \mathrm{v})$ at $22^{\circ} \mathrm{C}$, and at $1 \%$ and $0.5 \%(\mathrm{w} / \mathrm{v})$ at $4{ }^{\circ} \mathrm{C}, 0.2 \%$ being ineffective at this temperature. Temperature had an effect on the chemical inactivation of ASFV, with inactivation achieved at lower concentrations at $22^{\circ} \mathrm{C}$ than at $4^{\circ} \mathrm{C}(23)$. In cases of ASF disease obligating measures for decontamination, rooms, large surfaces, and means of transport are cleansed with a $2 \%$ caustic soda solution and $1 \%$ is used for hand disinfection. A $2 \%$ caustic soda solution is the strongest chemical compound inactivating ASFV.

Glutaraldehyde is an important dialdehyde that is used as a disinfectant and sterilant, in particular for low-temperature disinfection. Aqueous solutions of glutaraldehyde are acidic and generally, in this state, are not sporicidal $(23,34)$. It works most strongly at $\mathrm{pH}$ $7.5 \pm 0.85$. At other $\mathrm{pH}$ values, its action can be up to 36 times weaker. In the presence of organic impurities it is slightly less effective. Gram-positive and Gramnegative bacteria, fungi, and viruses are sensitive to glutaraldehyde, while bacterial spores and tuberculosis mycobacteria are moderately sensitive (25). Glutaraldehyde as a potentially virucidal agent is also used to inactivate ASFV. The actual action of the mechanism is unknown, but it involves destruction of the biological membranes by denaturing proteins, disturbance of metabolism protein-DNA cross-links, and capsid changes. It is non-corrosive to metal and does not damage lensed instruments, rubber, or plastics (34). That is why it is commonly used to sterilise plastics which cannot be sterilised by elevated temperature. It is toxic and a potential carcinogen, so glutaraldehyde exposure should be monitored to ensure safety during disinfection (25).

Phenol (phenolum) carbolic acid $\left(\mathrm{C}_{6} \mathrm{H}_{5} \mathrm{OH}\right.$, hydroxybenzene) has a crystalline form (whitish or colourless crystals) and emits a characteristic strong odour. It is one of the oldest antiseptic agents. Phenol is bacteriostatic at concentrations of $0.1 \%-1 \%$ and is bactericidal and fungicidal at 1\%-2\%. A 5\% solution kills anthrax spores in $48 \mathrm{~h}$. The bactericidal activity is enhanced by EDTA and warm temperatures; however, it is decreased by an alkaline medium (through ionisation), lipids, soaps, and low temperatures (45). In high concentrations, phenol acts as a gross protoplasmic poison, penetrating and destroying the cell wall and precipitating the cell proteins. Low concentrations of phenol and higher-molecular-weight phenol derivatives cause bacterial death, by inactivation of substantial enzyme systems and leakage of essential metabolites from the cell wall (34). Phenol has good penetrating power into organic matter and is mainly used for the disinfection of equipment or organic materials that are to be destroyed (e.g. infected food and excreta) (45). Phenolics are phenol derivatives. These biocides act through membrane damage and denaturation and coagulation of proteins. They are effective against enveloped viruses, including ASFV, rickettsia, fungi, and vegetative bacteria. They are also more active in the presence of organic material than other disinfectants. Cresols, hexachlorophene, alkyl- and chloro- derivatives, and diphenyls are more active than phenol itself (10). The phenol methyl derivative is cresol $\left(\mathrm{C}_{6} \mathrm{H}_{4}\left(\mathrm{CH}_{3}\right) \mathrm{OH}\right.$, hydroxytoluene) in the form of ortho, meta, and para isomers, cresol being a mixture of all three isomers. This is another important disinfectant with tenfold stronger disinfecting activity than phenol. Cresol is obtained by the distillation of coal tar. The mixture of cresols and resin soaps is creolin (creolinum), and the mixture of cresol and potassium soap is lysol (lysolum), which is used for the disinfection of instruments and medical equipment (in a concentration of $3 \%-5 \%$ ), hands (in a concentration of $1 \%-2 \%$ ), and floors, walls, and furniture (in a $5 \%-$ $10 \%$ concentration). Bathrooms are disinfected with a $10 \%$ solution. Cresol is a dark brown, thick liquid forming a suspension when mixed with water (33).

Quaternary ammonium compounds (QACs) are ionic compounds that contain four organic groups in the molecule and are linked to nitrogen atoms (including three covalent and one coordination bond). The amine rank is determined by the number of hydrogen atoms and free pairs of nitrogen electrons substituted with carbon atoms in the ammonia molecule. The hydrophilic element of the molecule is a nitrogen cation, and the hydrophobic fragment is an alkyl chain. This chemical structure provides unique activation properties at the interface and interaction with the surface (21). The surface activity of QACs is also determined by the length of the aliphatic carbon chain; the highest is in the presence of 12-14 carbon atoms. Many antimicrobial products contain mixtures of QACs and other additions to increase their efficacy or to target a specific group of organisms. QACs are membrane-active agents, interacting with the cytoplasmic membranes of bacteria. Their hydrophobic activity also makes them effective against enveloped viruses. QACs also interact with intracellular targets and bind to DNA. They are also effective against nonenveloped viruses and spores, depending on product formulation (13). 
Table 3. List of EPA-registered products for use against ASFV (43)

\begin{tabular}{|c|c|c|c|c|}
\hline EPA reg. no. & Product name* & Manufacturer & Active ingredient (s) & Pest and use site (s) \\
\hline $11-25$ & $\begin{array}{l}\text { Pheno-Cen Germicidal } \\
\text { Detergent }\end{array}$ & Central Solutions, Inc. & $\begin{array}{l}\text { o-Phenylphenol, } \\
\text { potassium salt p-tert- } \\
\text { Amylphenol, potassium } \\
\text { salt Potassium 2-benzyl- } \\
\text { 4- chlorophenate }\end{array}$ & $\begin{array}{l}\text { ASFV in livestock pens, manure, } \\
\text { equipment (livestock, feeding, and } \\
\text { watering, farm), hog farrowing houses, } \\
\text { hog houses, animal quarters, and shoe } \\
\text { baths }\end{array}$ \\
\hline $211-62$ & Low pH Phenolic 256 & Central Solutions, Inc. & $\begin{array}{l}\text { o-Phenylphenol } \\
\text { 2-benzyl-4-chorophenol }\end{array}$ & $\begin{array}{l}\text { ASFV in livestock premises, equipment } \\
\text { (feeding and watering, livestock), } \\
\text { livestock/animal transportation vehicles, } \\
\text { hog farrowing houses, hog barns/ } \\
\text { houses/sties/pens, farrowing equipment, } \\
\text { and shoe baths }\end{array}$ \\
\hline $69470-37$ & Clearon Bleach Tablets & Clearon Corp & $\begin{array}{l}\text { Sodium dichloro-s- } \\
\text { triazinetrione }\end{array}$ & $\begin{array}{l}\text { ASFV in/on animal living quarters, farm } \\
\text { premises, and shoe baths }\end{array}$ \\
\hline $71654-6$ & Virkon S & $\begin{array}{l}\text { E.I. du Pont de } \\
\text { Nemours \& Company }\end{array}$ & $\begin{array}{l}\text { Sodium chloride } \\
\text { potassium } \\
\text { peroxymonosulphate }\end{array}$ & $\begin{array}{l}\text { ASFV in animal feeding/watering } \\
\text { equipment, livestock barns, pens, stalls, } \\
\text { stables, equipment, hog farrowing pen } \\
\text { premises, hog barns/houses/sties/pens, } \\
\text { animal quarters, animal transportation } \\
\text { vehicles, agricultural premises, } \\
\text { agricultural equipment, and human } \\
\text { footwear }\end{array}$ \\
\hline $71847-2$ & KlorKleen & Medentech Ltd. & $\begin{array}{l}\text { Sodium dichloro-s- } \\
\text { triazinetrione }\end{array}$ & $\begin{array}{l}\text { ASFV in animal quarters and animal } \\
\text { living quarters }\end{array}$ \\
\hline $71847-6$ & Klorsept & Medentech Ltd. & $\begin{array}{l}\text { Sodium dichloro-s- } \\
\text { triazinetrione }\end{array}$ & $\begin{array}{l}\text { ASFV in/on animal quarters, animal } \\
\text { feeding/watering, animal equipment, } \\
\text { and animal transportation vehicles }\end{array}$ \\
\hline
\end{tabular}

QACs are widely used as disinfectants but are not recommended as antiseptics because on skin and tissue their failure was acknowledged following several outbreaks of infections associated with their use. They are commonly used in ordinary environmental sanitation of non-critical surfaces, such as floors, furniture, and walls. QACs show generally low toxicity, but prolonged contact with them can irritate the skin and respiratory tract. There are tests confirming that $0.003 \%$ concentration of QACs was very effective against four enveloped viruses, including the African swine fever virus. QACs induced detachment of the enveloped viruses and had a much stronger effect against these viruses than other disinfectants (37). ASFV is readily inactivated by lipid solvents because of its envelope (5). The mechanisms of action of main disinfectants are presented in Table 2.

There are many commercial disinfectants against ASFV based on the chemical compounds mentioned above. However, only some of them are recommended by the Environmental Protection Agency (EPA) in the USA for the combat of ASFV (Table 3).

\section{Conclusion}

Pig production is one of the most important aspects of the world's food economy, and it is extremely important to ensure the biosecurity of pig farms and their freedom from infectious diseases, especially diseases like ASF, which leads to almost $100 \%$ mortality.

Some viral diseases can be prevented and controlled by vaccination programmes, but, at the present time, neither vaccines nor safe and effective chemotherapeutic agents are available against ASFV. Effective isolation of infected pigs is often problematic or impractical, and a pig farmer usually relies heavily on chemical disinfection. Therefore, it is extremely important to select suitable virucidal disinfectants and to apply them effectively in reducing the transmission of viral diseases. Although there are some data from efficacy studies of some disinfectants, it seems necessary to perform tests directly on ASFV to ensure the maximum effectiveness of disinfectants and prevent the spread of ASF in the future. 
Considering the diversity and attributes of biocides presented here and the fact that ASFV is an enveloped virus, disinfection should be effective when the following certain conditions are met:

- mechanical cleaning is carried out with detergents, ensuring the removal of proteins,

- a recommended, tested, and approved disinfectant is used,

- the proper temperature is achieved,

- the recommended concentration of disinfectant is used,

- the recommended contact time is ensured.

Disinfection is one of the most important components of the whole biosecurity programme for the prevention of ASF. The conditions mentioned above should be strictly applied by all workers associated with piggeries.

Conflict of Interests Statement: The authors declare that there is no conflict of interests regarding the publication of this article.

Financial Disclosure Statement: Not applicable.

Animal Rights Statement: Not applicable.

\section{References}

1. Alphin R.L., Johnson K.J., Ladman B.S., Benson E.R.: Inactivation of avian influenza virus using four common chemicals and one detergent. Poult Sci 2009, 88, 1181-1185, doi: 10.3382/ps.2008-00527.

2. Ascenzi J.M.: Handbook of disinfectants and antiseptics. Marcel Dekker, New York, 2016, pp. 133-158.

3. Blackwell M., Kang H., Thomas A., Infante P.: Formaldehyde: evidence of carcinogenicity. Am Ind Hyg Assoc J 1981, 42, 34- 46.

4. Boone S.A., Gerba C.P.: Significance of fomites in the spread of respiratory and enteric viral disease. Appl Environ Microbiol 2007, 73, 1687-1696.

5. Burton C.H., Turner C.: Manure management: treatment strategies for sustainable agriculture, African swine fever virus. Silsoe Research Institute, 2003, 139.

6. Chan Y.F., Abu Bakar S.: Virucidal activity of Virkon S on human enterovirus. Med J Malaysia 2005, 60, 246-248.

7. Chang A.C., Zsak L., Feng Y., Mosseri R., Lu Q., Kowalski P., Zsak A., Burrage T.G., Neilan J.G., Kutish G.F., Lu Z., Laegreid W., Rock D.L., Cohen S.N.: Phenotype-based identification of host genes required for replication of African swine fever virus. J Virol 2006, 80, 8705-8717.

8. Cisek A.A., Dąbrowska I., Gregorczyk K.P., Wyżewski Z.: African swine fever virus: a new old enemy of Europe. Ann Parasitol 2016, 62, 161-167, doi: 10.17420/ap6203.49.

9. Dixon L.K., Abrams C.C., Bowick G,., Goatley L.C., Kay-Jackson P.C., Chapman D., Liverani E., Nix R., Silk R., Zhang F.: African swine fever virus proteins involved in evading host defence systems. Vet Immunol Immunopathol 2004, 100, 117-134.

10. Environmental health and safety, University of Colorado Boulder. Disinfect Sterilizat Methods 2008. https://ehs.colorado.edu/resources/disinfectants-and-sterilizationmethods/.

11. Frant M., Woźniakowski G., Pejsak Z.: African swine fever (ASF) and ticks. No risk of tick-mediated ASF spread in Poland and Baltic states. J Vet Res 2017, 61, 375-380, doi: 10.1515/jvetres-2017-0055.

12. Gallina L., Scagliarini A.: Virucidal efficacy of common disinfectants against orf virus. Vet Rec 2010, 166, 725-726, doi: 10.1136/vr.c3001.

13. Gerba C.P.: Quaternary ammonium biocides: efficacy in application. Appl Environ Microbiol 2015, 81, 464-469, doi: 10.1128/AEM.02633-14.

14. Jia N., Ou Y., Pejsak Z., Zhang Y., Zhang J.: Roles of African swine fever virus structural proteins in viral infection. $J$ Vet Res 2017, 6, 135-143, doi: 10.1515/jvetres-2017-0017.

15. Kalmar I.D., Cay A.B., Tignon M.: Sensitivity of African swine fever virus (ASFV) to heat, alkalinity, and peroxide treatment in presence or absence of porcine plasma. Vet Microbiol 2018, 219, 144-149, doi: 10.1016/j.vetmic.2018.04.025.

16. Koblentz G.D.: Biosecurity reconsidered: calibrating biological threats and responses. International security. Harvard College and the Massachusetts Institute of Technology 2010, 34, 96-132.

17. Kuliś M., Tylkowska-Siek A.: Farm animals in 2017. Statistics Poland, Agriculture Department, www.stat gov.pl./files/gfx/portalinformacyjny/pl/defaultaktualnosci/5508/6 /18/1/zwierzeta_gospodarskie_w_2017_roku.pdf

18. Kuliś M.: Pogłowie świn według stanu w marcu 2018 roku, Statistics Poland, Agriculture Department, www.stat gov.pl./files/gfx/portalinformacyjny/pl/defaultaktualnosci/5508/8 $/ 2 / 1 /$ poglowie swin wedlug stanu w marcu_2018_roku.pdf.

19. Levis D.G., Baker B.: Biosecurity of pigs and farm security. Institute of Agriculture and Natural Resources at the University of Nebraska-Lincoln, 2011, 1-31.

20. Lewis T., Zsak L., Burrage T.G., Lu Z., Kutish G.F., Neilan J.G.: An African swine fever virus ERV1-ALR homologue, 9GL, affects virion maturation and viral growth in macrophages and viral virulence in swine. J Virol 2000, 74, 1275-1285.

21. Lipińska-Ojrzanowska A., Walusiak-Skorupa J.: Quaternary ammonium compounds - New occupational hazards. Med Pracy 2014, 65, 675-682, doi: https://doi.org/10.13075/mp.5893. 00056.

22. Maillard J.Y.: Virus susceptibility to biocides: an understanding. Rev Med Microbiol 2001, 12, 63-74.

23. McDonnell G., Russell D.A.: Antiseptics and disinfectants: activity, action, and resistance, mechanisms of actions. Clin Microbiol Rev 1999, 12, 149-158.

24. Occupational Safety and Health Administration, 2011, www.osha. gov/OshDoc/data_General_Facts/formaldehyde-factsheet.pdf

25. Olesiak P., Stępniak L.: Effectiveness of selected disinfectants against Bacillus spores. Inżynieria i Ochrona Środowiska, 2012, $15,41-50$

26. Penrith M-L.: African swine fever. Onderstepoort J Vet Res 2009, 76, 91-95.

27. Penrith M.L., Guberti V., Depner K., Lubroth J.: Preparation of African swine fever contingency plans. FAO Rome 2009, 1-69.

28. Philippa C.H., Christopher L.N., Thomas E.W., Paul M.: The envelope of intracellular African swine fever virus is composed of a single lipid bilayer. J Virol 2008, 82, 7905-7912, doi: 10.1128/JVI.00194-08.

29. Porowski M.: Disinfection - myths and facts. National Veterinary Research Institute, Puławy, Poland, 2015, http://www.piwet.pulawy.pl/piwet7/files/ASF/pdf2/Marian\%20P orowski.pdf.

30. Przedpełski K.: Effective biosecurity, Krajowa Rada Izb Rolniczych, 2018, www.krir.pl/2014-01-03-03-24-03/afrykanski -pomor-swin/5585-skuteczna-biosakuracja.

31. Quintas A., Pérez-Núñez D., Sánchez E.G., Nogal M.L., Hentze M.W., Castelló A., Revillaa Y.: Characterization of the African swine fever virus decapping enzyme during infection. J Virol 2017, 91, 1-18

32. Revilla Y., Pérez-Núñez D., Richt J.A.: African swine fever virus biology and vaccine approaches. Adv Virus Res 2018, 100, 41-74, doi: 10.1016/bs.aivir.2017.10.002. 
33. Różański H.S.: Antiseptics and disinfectants used in medicine, 2001-2004. http://web.archive.org/web/20070508184957/http:// www.rozanski.henryk.gower.pl/antisepticum2002.htm.

34. Rutala W.A., Weber D.J., Healthcare Infection Control Practices advisory Committee: guideline for disinfection and sterilization in healthcare facilities, chemical disinfectants. Chapel Hill, 2008, $1-161$,

www.cdc.gov/infectioncontrol/pdf/guidelines/disinfection guidelines.pdf.

35. Sánchez-Cordón P.J., Montoya M., Reis A.L., Dixon L.K.: African swine fever: A re-emerging viral disease threatening the global pig industry. Vet $\mathrm{J}$ 2018, 233, 41-48, doi: 10.1016/j.tvj1.2017.12.025.

36. Sattar S.A.: Hierarchy of susceptibility of viruses to environmental surface disinfectants: a predictor of activity against new and emerging viral pathogens. J AOAC Int 2007, 90, $1655-1658$.

37. Shirai J., Kanno T., Tsuchiya Y., Mitsubayashi S., Seki R.: Effects of chlorine, iodine, and quaternary ammonium compound disinfectants on several exotic disease viruses. J Vet Med Sci 2000, 62, 85-92.

38. Springthorpe V.S., Sattar S.A.: Chemical disinfection of virus-contaminated surfaces. Critical Rev Environ Control 2009, $20,169-229$.

39. Thurman R.B., Gerba C.P.: Molecular mechanisms of viral inactivation by water disinfectants. Adv Appl Microbiol 1988, $33,75-105$.

40. Trzcińska A., Częścik A., Łagosz B., Siennicka J.: Vaccinia virus (MVA) as a virus model in the study of virucidal activity of disinfectants against enveloped viruses (in Polish). Med Dosw Mikrobiol 2017, 69, 133-141.

41. Turner C., Williams S.M.: Laboratory-scale inactivation of African swine fever virus and swine vesicular disease virus in pig slurry. J Appl Microbiol 1999, 148-157.

42. Turner C., Burton C.H.: The inactivation viruses in pig slurries: a review. Bioresour Technol 1997, 61, 9-20.

43. USDA APHIS.: Potential pesticides to use against the causative agents of selected foreign animal disease in farm settings. 2011, 2. www.aphis.usda.gov/animal_health/emergency_management/ downloads/fad_epa_disinfectants.pdf.

44. Vepkhvadze N.G., Menteshashvili I., Kokhreidze M., Goginashvili K., Tigilauri T., Mamisashvili E., Gelashvili L., Abramishvili T., Donduashvili M., Ghvinjilia G., Avaliani L., Parkadze O., Ninidze L., Kartskhia N., Napetvaridze T., Rukhadze Z., Asanishvili Z., Weller R., Risatti G.R.: Active surveillance of African swine fever in domestic swine herds in Georgia, 2014. Rev Sci Tech 2017, 36, 879-887, doi: 10.20506/rst.36.3.2721.

45. Wickstrom M.L.: Phenols and related compounds. www. merckvetmanual.com/pharmacology/antiseptics-and-disinfectants/ phenols-and-related-compounds\#v3338414.

46. World Organisation for Animal Health - OIE.: Technical disease card for African swine fever, 2009, www.oie.int/fileadmin/ Home/eng/Our_scientific_expertise/docs/pdf/AFRICAN\%20SW INE\%20FEVER.pdf.

47. World Organisation for Animal Health - OIE: Terrestrial animal health code, general recommendations on disinfection and disinsectisation, Paris, 2011, 1, 169. 